\title{
Systemic toxicity after isolated limb perfusion with melphalan for melanoma
}

\author{
Eric J. A. Sonneveld*, Bart C. Vrouenraets*, Bert N. van Geel $\dagger$, \\ Alexander M. M. Eggermont $\dagger$, Joost M. Klaase*, Omgo E. Nieweg*, \\ Joop A. van Dongen* and Bin B. R. Kroon* \\ *Department of Surgery. The Netherlands Cancer Institute (Antoni van Leeuwenhoek Ziekenhuis). \\ Amsterdam, $\dagger$ Department of Surgery, Dr Daniel den Hoed Cancer Center, Rotterdam, The Netherlands
}

\begin{abstract}
Systemic exposure to melphalan is minimized during isolated limb perfusion (ILP) by isolating a limb from the rest of the body. Consequently, there should be no toxicity to vital organs. At present systemic toxicity after ILP has not been studied in detail. Therefore, the incidence, nature and risk factors of systemic toxicity was retrospectively studied in 368 patients who underwent a single ILP with melphalan between 1978-1990. Some form of systemic toxicity occurred in 98 patients $(27 \%)$. Nausea and vomiting after the Ist post-ILP day was seen in 73 patients $(20 \%)$, and in seven $(2 \%)$ treatment was required. Bone marrow depression was encountered in seven patients (2\%): WHO grade II in five, and grade III in two. Miscellaneous systemic side-effects, including fever and minimal scalp hair loss, occurred in 19 patients (5\%). Leakage from the isolated circuit to the systemic circulation was measured with radioactive tracers. Mean cumulative leakage during ILP was $0.9 \%$. Systemic toxicity was not increased in patients with leakage greater than $1 \%$ or $5 \%$. Female sex was associated with increased incidence of systemic toxicity $(P<0.05)$. Age over 60 years $(P<0.05)$ and more severe acute regional toxicity $(P<0.05)$ were correlated with nausea and vomiting. The miscellaneous systemic side-effects were more frequently encountered in women than in men $(P<0.05)$. In conclusion, systemic toxicity was rarely severe, with nausea and vomiting being the most frequently encountered side-effects. Age over 60 years, female sex and more severe acute regional toxic reactions were correlated with an increased incidence of systemic side-effects. Systemic leakage during ILP was not associated with toxicity, probably due to the low incidence of significant leakage.
\end{abstract}

Key words: isolated limb perfusion; systemic toxicity; melphalan; melanoma.

Introduction

Isolated limb perfusion (ILP) was introduced by Creech $e t$ al. in 1958.' Nowadays, it is an established procedure in the treatment of locally inoperable and recurrent melanoma. ${ }^{2-8}$

The main advantage of ILP is that a high dose of cytostatic drug (usually melphalan) can be given loco-regionally, thereby minimizing systemic exposure to the drug and subsequent toxicity to vital organs. The concentration of melphalan in the perfusion circuit is approximately 10 times higher than the concentration in blood after maximumtolerated doses normally used for systemic administration. ${ }^{9.10}$ During ILP, the melphalan peak concentration is about 150 times higher in the perfusate than in the systemic circulation." Therefore, optimal isolation of the limb is of utmost importance to avoid leakage of the drug into the systemic circulation. Toxicity after systemic administration

Correspondence 10: Dr B. B. R. Kroon, Department of Surgery, The Netherlands Cancer Institute (Antoni van Leeuwenhoek Ziekenhuis), Plesmanlaan 121, $1066 \mathrm{CX}$ Amsterdam, The Netherlands. of malphalan includes bone marrow depression, gastrointestinal toxicity such as nausea and vomiting, diarrhoea and stomatitis, hair loss, maculopapular rashes and pruritis. $^{\text {2 }}$

Published data on systemic toxicity after ILP vary widely and, given the retrospective nature of most reports, all figures probably represent minimum estimates. ${ }^{3}$ Mortality rates as high as $9 \%$ have been reported after ILP, ${ }^{13}$ mainly from the beginning of the perfusion era. ${ }^{2.14-16}$ Bone marrow depression is encountered in a wide range of $0-59 \%$ of perfused patients, ${ }^{14.16-40}$ but data on other potential sideeffects are scarce. Detailed information on aetiology and risk factors for systemic toxicity after ILP with melphalan is lacking. A better understanding of the influence of patientand treatment-related factors on systemic toxicity could lead to improvements in ILP technology and to the prevention of side-effects.

Moreover, systemic toxicity has become of major concern with the recent introduction of tumour necrosis factor-alpha (TNF $\alpha$ ) in ILP," as TNF $\alpha$ has been associated with severe and sometimes life-threatening complications. ${ }^{41-44}$

In this study, we present our experiences with systemic toxicity after single ILP with melphalan with respect to incidence, nature and risk factors. 
Table 1. Distribution of patient- and ILP-related variables

\begin{tabular}{|c|c|}
\hline & $\begin{array}{c}\text { No. of patients ("1/n) } \\
\qquad(n=368)\end{array}$ \\
\hline $\begin{array}{l}\text { Sex } \\
\text { male } \\
\text { fenale }\end{array}$ & $\begin{array}{r}98(27) \\
270(73)\end{array}$ \\
\hline $\begin{array}{l}\text { Age (year) } \\
<60 \\
\geq 60\end{array}$ & $\begin{array}{l}229(62) \\
139(.38)\end{array}$ \\
\hline $\begin{array}{l}\text { Level of isolation } \\
\text { axillary } \\
\text { brachial } \\
\text { iliac } \\
\text { femero-popliteal }\end{array}$ & $\begin{array}{r}51(14) \\
9(2) \\
257(70) \\
51(14)\end{array}$ \\
\hline $\begin{array}{l}\text { Tissue temperalure } \\
37-38^{\circ} \mathrm{C} \\
39-40^{\circ} \mathrm{C} \\
41-42^{\circ} \mathrm{C}\end{array}$ & $\begin{array}{r}306(83) \\
44(12) \\
18 \quad(5)\end{array}$ \\
\hline $\begin{array}{l}\text { Total dose of melph } \\
\quad \leq 120 \\
>120\end{array}$ & $\begin{array}{r}306(83) \\
62(17)\end{array}$ \\
\hline $\begin{array}{l}\text { Leakage to systemic } \\
\leq 1 \% \% \\
>1 \% \% \\
\text { unknown }\end{array}$ & $\begin{array}{r}298(81) \\
39(11) \\
31 \quad(8)\end{array}$ \\
\hline $\begin{array}{l}\text { Acule regional toxic } \\
\text { grade I-II } \\
\text { grade III-V }\end{array}$ & $\begin{array}{r}309(84) \\
59(16)\end{array}$ \\
\hline
\end{tabular}

\section{Patients and methods}

A total of 499 ILPs in 431 patients with melanoma of the limbs were performed in our institutes in the period 1978-1990. ILPs performed after 1990 were not included in this study because of the frequent use of multiple ILP schedules and the introduction of TNF $x$. A computerassisted database, containing all patient, tumour and treatment characteristics. allowed the selection of 368 patients who underwent a single ILP with melphalan. It comprised 270 women $(73 \%)$ and 98 men $(27 \%)$ with a mean age of 52 years (range: 17-83). One-hundred and fifty-eight patients $(43 \%)$ underwent ILP for primary melanoma and 210 patients $(57 \%)$ for recurrent melanoma. Patient and ILP characteristics are summarized in Table 1.

Our single ILP methodology has been described previously in detail. ${ }^{8.45}$ Isolation of the limb was achieved by dissecting and cannulating the main supplying artery and vein, and ligating or clamping the main collaterals. For the axillary and iliac isolation levels, a Steinmann pin was inserted into the head of the humerus or anterior superior iliac spine, around which an occluding Esmarch rubber bandage was fixed and twisted around the root of the limb, proximal to the region of perfusion. This technique prevents collateral circulation in muscles, subcutaneous tissues and skin. In ILPs at the more distal brachial and femoropopliteal isolation levels, an inflating tourniquet was used. Fifty-one ILPs $(14 \%)$ were at the axillary, nine $(2 \%)$ at the brachial, $257(70 \%)$ at the iliac and $51(14 \%)$ at the femoropopliteal isolation level.
We essentially focused on the maintenance of normal physiology in the limb during ILP. .5 $^{5}$ 'Controlled" normothermia (tissue temperatures between $37^{\circ} \mathrm{C}$ and $38^{\circ} \mathrm{C}$ ) was routinely applied in 306 ILPs and 'mild' hyperthermia $\left(39-40^{\circ} \mathrm{C}\right)$ was administered in 44 , which were carried out in the framework of the prospective randomized $\mathrm{WHO}$ EORTC trial for high-risk stage I melanoma. ${ }^{\text {th }}$ Eighteen patients had been perfused using borderline "true" hyperthermia $\left(41-42^{\circ} \mathrm{C}\right) .^{+7}$ Melphalan was routinely given in a dose of $10 \mathrm{mg} / \mathrm{l}$ tissues for lower and $13 \mathrm{mg} / \mathrm{l}$ for upper limb ILPs. ${ }^{4.44}$ Mean melphalan dose given was $91.4 \mathrm{mg}$ (range: $18.0-165.0 \mathrm{mg}$ ). Sixty-two patients (17"11) received more than $120 \mathrm{mg}$ melphalan in the perfusion circuit. The priming volume of the extracorporal circuit was approximately $750 \mathrm{ml}$ and consisted of whole blood diluted with physiological electrolyte solutions to a haematocrit of approximately 30 .

The perfusion procedure was flow-regulated. The optimal flow rate was considered to be the highest possible flow without increasing the venous pressure more than $10 \mathrm{~cm}$ above the starting point and with less than $5 \%$ leakage to the systemic circulation. A minimal flow rate of $40 \mathrm{ml} /$ $\mathrm{min} / \mathrm{l}$ perfused tissue is generally sufficient, and provides physiological blood gas values. The venous pressure in the isolated limb was monitored in a peripheral vein at a distal site. Any leakage to the systemic circulation was measured with a radioactive tracer. A small calibration dose of radioactively labelled human serum albumine (labelled with technetium- $99 \mathrm{~m}$ or iodine-131) was given to the systemic circulation and a higher dose of the same radiopharmaceutical to the isolated limb. Continuous monitoring was performed with a precordial scintillation probe. Systemic leakage was quantitatively expressed as a percentage. whereby a $100 \%$ leak was considered to give a homogeneous distribution of the tracer in the body. ${ }^{5}$ The perfusion duration was $1 \mathrm{~h}$ in all ILPs. The mean cumulative systemic leakage after $60 \mathrm{~min}$ of ILP was $0.9 \pm 1.9 \%$ (range: $0-15.6 \%$. Systemic leakage was $1 \%$ or less in 298 patients $(81 \%)$ and more than $1 \%$ in 39 patients $(11 \%)$. Nine patients (3\%) had more than $5 \%$ leakage during ILP, two of them $(0.5 \%)$ having more than $10 \%$. Leakage was not determined in 31 patients $(8 \%)$, most of whom had ILP at a distal isolation level, where systemic leakage is seldom substantial.

After the ILP procedure, patients spent one night in the Intensive Care Unit. Prophylactic antiemetics were not administered. However, most patients required these drugs in the first $6-12 \mathrm{~h}$ post-ILP.

The acute regional toxicity after ILP was graded according to Wieberdink et al. (Table 2). ${ }^{48}$ No, or only slight, skin toxicity after ILP (grade I-II) was found in 309 patients $(84 \%)$ and 59 patients $(16 \%)$ encountered more pronounced acute regional toxicity (grade III-V). The mean hospital stay after ILP was 23 days (range: 7-147 days).

As indicators of systemic toxicity we looked at the incidence of nausea and vomiting, bone marrow depression, and miscellaneous side-effects. Nausea/vomiting and bone marrow depression as expressed by white blood cell counts were graded according to the WHO-criteria (Table 3). ${ }^{51}$ In 70 patients (19\%). the number and/or timing of white blood cell counts was not sufficient to draw any conclusions concerning the presence or absence of bone marrow 
Table 2. Classification of acute regional tissue reactions according to Wieberdink et al. ${ }^{48}$

$\begin{array}{ll}\text { Grade I } & \text { No subjective or objective evidence of reaction } \\ \text { Grade II } & \text { Slight erythema and/or oedema } \\ \text { Grade III } & \text { Considerable erythema and/or oedema with some blistering; slightly disturbed motility permissible } \\ \text { Grade IV } & \text { Extensive epidermolysis and/or obvious damage to the deep tissues, causing definite functional disturbances; } \\ & \text { thireatening or manifest compartmental syndromes } \\ \text { Grade V } & \text { Reaction which may necessitate amputation }\end{array}$

Table 3. Grading of systemic toxicity after perfusion according to WHO ${ }^{\text {s2 }}$

\begin{tabular}{ll}
$\begin{array}{ll}\text { Nausea/vomiting } \\
\text { grade I }\end{array}$ & nausea \\
grade II & transient vomiting \\
grade III & voniting requiring therapy \\
grade IV & intractable vomiting \\
\multicolumn{2}{c}{ Bone matrow depression } \\
grade I & WBC $3.0-3.910^{9} / 1$ \\
grade II & WBC $2.0-2.910^{9} / 1$ \\
grade III & WBC $1.0-1.910^{\circ} / 1$ \\
grade IV & WBC $<1.010^{\circ} / 1$
\end{tabular}

WBC: white blood cell count.

depression. Leucocyte counts of less than $3.0 \times 10^{9} / 1$ were considered indicators of significant bone marrow depression (WHO grade II-III). Nausea and/or yomiting was considered as showing significant systemic toxicity when it occurred (or was still present) more than $24 \mathrm{~h}$ after ILP. The following patient- and treatment-related factors were tested using the chi-square method for their influence on systemic side-effects: sex, age ( $<60$ vs $\geq 60$ years), total dose of melphalan ( $\leq 120 \mathrm{vs}>120 \mathrm{mg}$ ), systemic leakage ( $\leq 1 \mathrm{vs}$ $>1 \%$ and $\leq 5$ vs $>5 \%$ ) and acute regional toxicity (grade I-II vs III-V).

\section{Results}

There was no post-operative mortality in the selected 368 patients. Some form of systemic toxicity during hospital stay occurred in 98 patients $(27 \%)$, including nausea/ vomiting after the first post-operative day in 73 patients ( $20 \%$ of the 368 patients), which required the administiation of antiemetics (domperidon, metoclopramide, droperidol) in seven patients ( $2 \%$ ) (Fig. 1). Bone marrow depression was encountered in 32 patients $(9 \%)$ grade I in $25(7 \%)$; grade II in five (1.5\%) and grade III in two patients $(0.5 \%)$ (Fig. 2). The white blood cell coints reached their nadir after a median period of 6 days in patients with grade $I$, and 14 days in patients with grade II and III bone marrow depression. Bone marrow depression was transient in all cases. Other systemic side-effects, such as fever and minor scalp hair loss, occurred in 19 patients $(5 \%)$ and are listed in Table 4.

Table 5 shows the patient- and perfusion-related variables tested ( $\chi^{2}$-test) as possible risk factors for systemic toxicity. Sex appeared to be a significant factor associated with systenic toxicity $(P<0.05)$, with women having a higher probability of developing systemic side-effects. Systemic toxicity also seemed to be somewhat higher in patients who

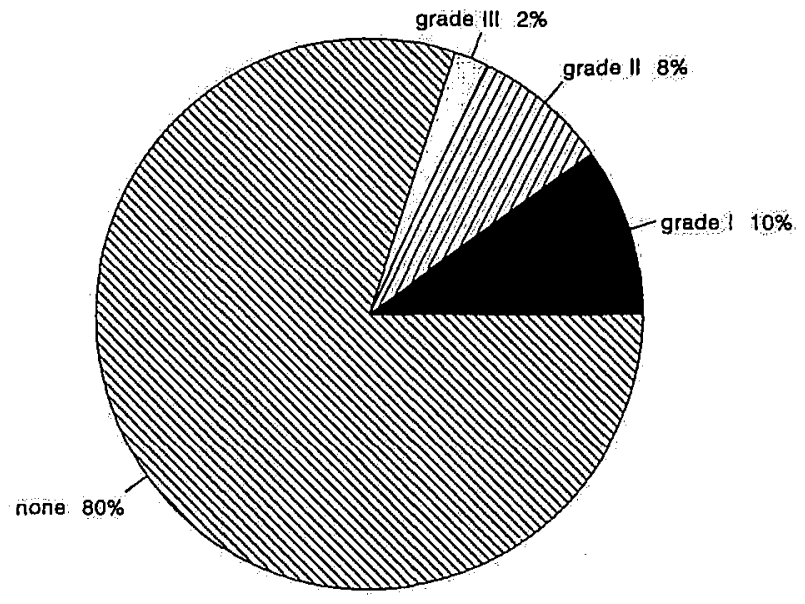

Fig. 1. Nausea and vomiting after ILP with melphalant.

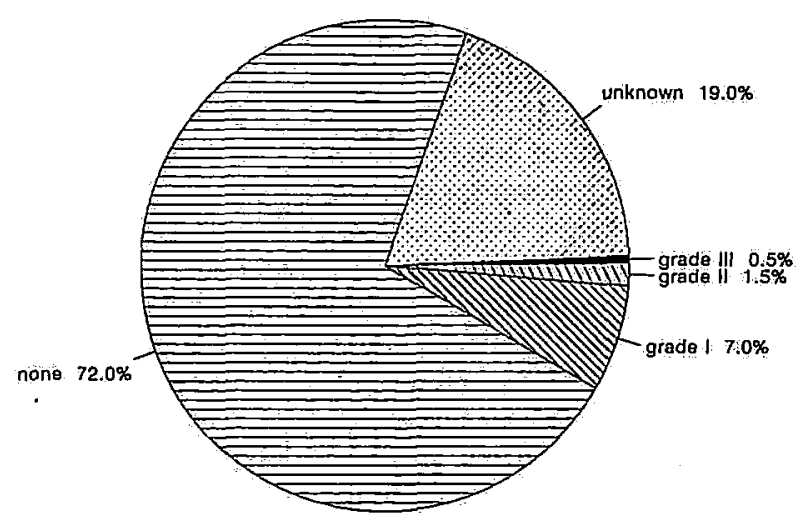

Fig. 2. Bone marrow depression after ILP with melphalan.

Table 4: Distribution of miscellaneous systemic side-effects $(N=19)$.

\begin{tabular}{lcc}
\hline Side-effect & $n$ & $(\%)$ \\
\hline Fever & 10 & $(2.7 \%)$ \\
Minimal scalp bair loss & 2 & $(0.5 \%)$ \\
Mild biochemical hepatotoxicity & 2 & $(0.5 \%)$ \\
Reversible renal failure not necessitating dialysis & 2 & $(0.5 \%)$ \\
Other (supraventricular tachycardia, myocardial & 3 & $(0.8 \%)$ \\
infarction, gastric bleeding) & 3 & ( \\
\hline
\end{tabular}

received more than $120 \mathrm{ng}$ melphalan in the perfusion circuit $(P=0.10)$.

All variables were also tested for their influence on the different forms of systemic toxicity (Table 5). Age over 60 years $(P<0.05)$ and more severe acute regional toxicity 
$(P<0.05)$ were both correlated with post-operative nausea and vomiting. Bone marrow depression seemed to occur more frequently in patients who received more than $120 \mathrm{mg}$ melphalan $(P<0.10)$ and these patients tended also to have more severe limb toxicity $(P<0.10)$. The miscellaneous systemic side-effects occurred significantly more frequently in women than in men $(P<0.05)$.

No correlation was found between the occurrence of systemic toxicity and leakage greater than $1 \%$. Also none of the separate forms of systemic toxicity was associated with leakage. Also leakage of $5 \%$ or more could not predict systemic side-effects. In the two patients with grade III bone marrow depression, systemic leakage was less than $1 \%$. None of the seven patients with vomiting requiring therapy had a systemic leak greater than $1 \%$. High systemic leakage (more than $10 \%$ ) was found in only two patients (15.0 and $15.6 \%$, respectively). Neither developed bone marrow depression but the latter appeared to have nausea and fever post-operatively.

\section{Discussion}

Mortality during the post-operative period was not seen in present series of 368 patients. In the literature, mortality rates after ILP with melphalan range from $0-9 \% \%^{13}$ (Table 6), ${ }^{1+.16-40}$ with deaths mainly occurring in the early years of ILP experience..$^{2.1416}$ Mortality usually results from pulmonary emboli, cardiac failure, renal failure, or bone marrow depression. 14, $16 \cdot 18,25,32,35,37^{2}$

The incidence of severe systemic toxicity after a single 'ILP with melphalan was minimal in the present series. Leucopenia (white blood cell counts $<1.0 \times 10^{9} /$. WHO grade IV toxicity) was not encountered. Only two patients $(0.5 \%)$ developed transient grade III bone marrow depression. Most patients had nausea and/or vomiting during the first 6-12 h following ILP. Intractable vomiting was not seen post-operatively, $2 \%$ of the patients required conventional antiemetic treatment after the first postoperative day with satisfactory results. Marked stomatitis, diarrhoea, maculopapular rashes and pruritis, commonly observed after the systemic administration of melphalan, ${ }^{12}$ were not seen. Minimal scalp hair loss was seen in only two patients $(0.5 \%)$, but without a striking aesthetic effect.

The absence of severe systemic toxicity can be explained by the low percentage of leakage to the systemic circulation during ILP in our series. ${ }^{52}$ Leakage of cytostatic drug has been associated with the occurrence of systemic sideeffects. ${ }^{5.26,33.34,38}$ It is known from literature data that total leakage values during ILP up to $15 \%$ do not cause severe systemic toxicity. ${ }^{53}$ When melphalan is given in a single dose at the start of ILP, as in our series, the concentration of melphalan in the perfusate declines rapidly during the early phase of drug circulation; there is a $40-50 \%$ decrease after $10 \mathrm{~min}$ of ILP and after $30 \mathrm{~min}$ almost all melphalan has accumulated in the tissues. ${ }^{4,10.54}$ Therefore, it is not surprising that melphalan toxicity to the bone marrow was clearly related to greater leakages during the first 5-10 min of ILP in other studies. ${ }^{26.38}$ Hence, melphalan should not be administered until haemodynamics have stabilized, and there should be no leakage of the perfusate into the systemic circulation.

On the other hand, systemic toxicity occurred to some extent in about one-quarter of perfused patients. In most cases this was gastro-intestinal toxicity with nausea, retching and transient vomiting which usually started in the immediate post-operative period lasting for more than $24 \mathrm{~h}$. We feel that nausea and vomiting is more pronounced after ILP compared with other surgery of the same duration and extent. These symptoms can be particularly distressing after ILP at the iliac level (which requires a sizeable incision through the musculature of the iliac fossa) because they cause a great deal of additional pain. ${ }^{55}$ Patients older than 60 years were significantly more frequently affected by this complication than younger patients in our series. However, these side-effects cannot be attributed completely to the melphalan alone as vomiting has also been reported in $10-50 \%$ of patients following routine surgery with general anaesthesia. ${ }^{56}$ Besides, melphalan leakage during ILP was not associated with prolonged post-operative nausea and vomiting in the present study. Maybe the combination of melphalan, anaesthetic agents, major surgery and postoperative narcotic analgesics given to control pain, is a powerful emetogenic stimulus. ${ }^{19.55}$ Pain itself and the release of waste products from the perfused limb may also be involved, as in our series more severe limb toxicity was associated with nausea and vomiting.

The recently developed serotonin antagonists provide excellent antiemetic control in patients treated with systemic chemotherapy or following surgery. ${ }^{57.51} \mathrm{~A}$ single $8 \mathrm{mg}$ dose of ondansetron (Zofren ${ }^{\star *}$ ) given intravenously at the time of anaesthetic induction has been reported to be effective in controlling nausea and vomiting in the great majority of patients after ILP.ss As most of our patients required antiemetic therapy in the first hours post-operatively. it seems better to anticipate vomiting by the prophylactic administration of these drugs.

Due to differences in what investigators are willing to list as significant bone marrow depression following ILP, it is difficult to compare our results with those of others. In $9 \%$ of our patients white blood cell counts passed the lower limit of normal during hospital stay $\left(4.0 \times 10^{y} / \mathrm{l}\right)$. However, for patients with grade I bone marrow depression the timing of the maximum fall suggested that it was related to fluid shifts rather than a drug effect. ${ }^{62.63}$ The incidence of significant bone marrow depression (as expressed by white blood cell counts lower than $\left.3.0 \times 10^{\%} / \mathrm{l}\right)$ in our series $(2 \%)$ is low-compared with literature data, where bone marrow depression is reported in up to $59 \%$ of perfused patients (Table 6). ${ }^{14,16-40}$

As systemic leakage during ILP was not significantly associated with bone marrow depression, a phenomenon reported before..$^{5.19}$ other factors may have played a role in our series, such as the total dose of melphalan. This link between total drug dose and enhanced bone marrow depression has also been noticed by other investigators. ${ }^{63.64}$ Despite very careful wash-out procedures, systemic peak concentrations of melphalan have been observed after reconnection of the perfused limb to the systemic circulation. ${ }^{40.52}$ Systemic drug levels after ILP may derive from the intravascular components of the limb $b^{11.40,52}$ or via 
Table 5. Risk factors for systemic toxicity after ILP with melphalan

\begin{tabular}{|c|c|c|c|c|}
\hline & Systemic toxicity & $N / V^{*}$ & $\mathrm{BMD} \dagger$ & Miscellaneous \\
\hline $\begin{array}{l}\text { Sex } \\
\text { (ठ vs \&) }\end{array}$ & $P<0.05$ & NS & NS & $P<0.05$ \\
\hline $\begin{array}{l}\text { Age (years) } \\
(<60 \text { vs } \geq 60)\end{array}$ & NS & $P<0.05$ & NS & NS \\
\hline $\begin{array}{l}\text { Total dose }(\mathrm{mg}) \\
(\leq 120 \text { vs }>120)\end{array}$ & $P=0.10$ & NS & $P<0.10$ & NS \\
\hline $\begin{array}{l}\text { Leakage }(1 / 11) \\
(\leq \mathrm{vs}>1)\end{array}$ & NS & NS & NS & NS \\
\hline $\begin{array}{l}\text { Regional toxicity } \\
\text { (grade I-II vs III-V) }\end{array}$ & NS & $P<0.05$ & $P<0.10$ & NS \\
\hline
\end{tabular}

*Nausea and vomiting grade I-III according to WHO criteria.

†Bone marrow depression grade II-III according to WHO criteria. NS = not significant.

release of the tissue-bound drug. ${ }^{5}$ Therefore, the total dose of melphalan employed may be related to the amount entering the systemic circulation after ILP and so may be responsible for systemic toxicity.

In $3 \%$ of our patients fever $\left(38-40^{\circ} \mathrm{C}\right)$ was noted in the immediate post-operative period without any evidence of infection. Fever has been reported to occur in up to $42 \%$ of patients following ILP with melphalan. ${ }^{65}$ It could be a result of the surgical trauma itself, the inflammatory state of the perfused limb. ${ }^{6 / 6}$ necrosis of muscle. ${ }^{67}$ or induction of host-mediators. ${ }^{6}$ Treatment is usually not required after exclusion of possible infectious aetiologies.

The reason why women had an increased risk on systemic side-effects is not understood and can only be speculated.

Our rather long mean hospital stay of approximately 3 weeks included a routine 3 day pre-operative work-up period

Table 6. Systemic toxicity after ILP with melphalan: review of the literature

\begin{tabular}{|c|c|c|c|c|c|}
\hline Author & Period & $N^{*}$ & $\mathrm{BMD}(1 / 11)$ & SHL(\%) & Mortality(1/1) \\
\hline \multirow[t]{2}{*}{ Stehlin ${ }^{17.15}$} & 1958-1964 & 221 & 1.8 & - & 0.5 \\
\hline & $1967-1974$ & 185 & - & - & 1.1 \\
\hline Irvine ${ }^{19}$ & $1966 t$ & 29 & 31 & - & 0 \\
\hline Shingleton ${ }^{211}$ & $1961-1968$ & 35 & 14 & - & 0 \\
\hline McBride ${ }^{16}$ & $1958-1969$ & 678 & 1.2 & - & 0.7 \\
\hline Fontaine ${ }^{21}$ & $1974 t$ & 56 & 5 & - & 0 \\
\hline Golomb:2 & $1959-1976$ & 114 & 23 & - & 0 \\
\hline Hansson ${ }^{23}$ & $1966-1974$ & 22 & 32 & 9 & 0 \\
\hline Jönsson ${ }^{24}$ & $1976-1981$ & 80 & 0 & - & 0 \\
\hline \multirow[t]{2}{*}{ Lejeune $e^{25.26}$} & $1983 \dagger$ & 23 & 26 & - & 9 \\
\hline & $1989+$ & 206 & 1 & - & 1 \\
\hline Rege $^{27}$ & $1962-1979$ & 39 & 0 & - & 3 \\
\hline Minor $^{28}$ & $1985 t$ & 28 & 7 & - & 0 \\
\hline Fletcher ${ }^{2 \prime \prime}$ & $1965-1983$ & 23 & 4.3 & - & 0 \\
\hline \multirow[t]{3}{*}{ Krementz ${ }^{14}$} & $1957-1966$ & 317 & 12.2 & 3.8 & 2.5 \\
\hline & $1967-1974$ & 278 & 4.0 & 0.7 & 0.4 \\
\hline & $1975-1982$ & 275 & 3.6 & 0 & 0 \\
\hline Vaglini" & $1982-1985$ & 95 & 5 & - & 0 \\
\hline Krige $^{31}$ & $1976-1982$ & 93 & 3 & - & 0 \\
\hline Di Filippo ${ }^{32}$ & $1969-1986$ & 136 & 35 & - & 5.9 \\
\hline Santinami ${ }^{33}$ & $1981-1987$ & 140 & 3.5 & - & 0 \\
\hline Kettelhack ${ }^{34}$ & 1982-1989 & 113 & 1.8 & - & 0 \\
\hline $\mathrm{Pace}^{3 / 3}$ & $1990 \dagger$ & 111 & 18 & 3.6 & 0.9 \\
\hline Skene $^{36}$ & $1979-1987$ & 91 & 7 & - & 2 \\
\hline Hafström ${ }^{37}$ & $1981-1989$ & 33 & 3 & - & 3 \\
\hline Neades $^{28}$ & $1985-1989$ & 26 & 31 & 8 & 0 \\
\hline Omlor" & 1989-199] & 36 & - & 6 & 0 \\
\hline Rauschecker ${ }^{10}$ & $1990 \dagger$ & 44 & 59 & - & - \\
\hline
\end{tabular}

*Number of ILPs (if not known: number of patients). BMD: bone marrow depression.

SHL: scalp hair loss.

† Year of publication 
and reflects merely the duration of the acute regional toxic reactions in the perfused limb. During the study period. patients were only discharged when fully mobilized.

In contrast with the negligible incidence of severe systemic side-effects after modern ILP with melphalan. the complications associated with the recently introduced biological response modifier TNF $\alpha$ in ILP can be impressive. Application of high doses of TNF $\alpha$, in contrast to melphalan, maintains high stable drug levels in the perfusate throughout the ILP." and can lead to prolonged high systemic levels and induce a systemic inflammatory response syndrome comprising fever and chills. hypotension and ARDS. ${ }^{+1+1.69 .70}$ This toxicity is directly correlated to leakage during ILP and can be almost completely prevented by adequate leakage control and extensive washout procedures at the end of the ILP.+1.71 It is also our experience that when leakage is abolished and thorough washout is performed. only a short-lived (less than $(\mathrm{h}$ ) systemically measurable TNF $x$-peak is observed and systemic toxicity is restricted to the induction of fever and limited to the day of ILP. ${ }^{72}$

In conclusion. systemic toxicity occurred in one-quarter of our patients after ILP with melphalan but was rarely severe, probably as a result of the low systemic leakage percentage. Nausea and vomiting were the most frequently encountered side-effects. Age over 60 years. female sex and more severe limb toxicity proved to be factors associated with an increased incidence of systemic side-eflects, drug leakage during ILP was not. These prognostic factors should be considered in attempts to decrease systemic toxicity after ILP.

\section{Acknowledgements}

The authors thank G. W, van Slooten and M. Wijers-Hille. perfusion technicians. who were closely involved in the perfusions and the research based on them and the laboratories of nuclear medicine of both hospitals for their indispensable assistance.

\section{References}

1. Creceh O Jr. Krementz ET, Ryan RF, Winblad JN. Chemotherapy of cancer: regional perfusion utilizing an extracorporal circuit. Alm Surg 1958: 148: 616-32.

2. Krementz ET. Carter RD. Sutherland CM. Muchmore JH, Ryan RF. Creech O Jr. Regional chemolherapy for melanoma: a 35-year experience. Amm Surg 1994: 220: 520-35.

3. Coit DG. Hyperthermic isolation limb perfusion for malignant melanoma: a review. Cancer $/ n$. 1992: 10: 277-84.

4. Hafström L, Mattsson J. Regional chemotherapy for malignant melanoma. Cancer Treal Rev 1993; 19: 17-28.

5. Bowers GJ. Copeland EM. Surgical limb perfusion for extremity melanoma. Surg Oncol 1994; 3: 91-102.

6. Rosin RD. Isolated limb perfusion. In: Kirkham N. Cotton DWU, (eds). Diagnosis and Management of Melanoma. BerlinHeidelberg: Springer Verlag. 1992: 123-34.

7. Thompson JF. Gianoutsos MP. Isolated limb perfusion for melanoma: effectiveness and toxicity of cisplatin compared with that of melphalan and other drugs. World J Surg 1992; 16: 227-33.

8. Vrouenraets BC. Klaase JM. Van Geel AN, et al. Regional isolated limb perfusion in patients with malignant melanoma. Onkologie 1993: 16: 163-9.
9. Briele HA. Djuric M. Jung DT, Mortell T, Patel MK. Das Gupta TK. Pharmacokineties of melphalan in clinical isolation perfusion of the extremities. Cancer Res 1985: 45: 1885-9.

10. Harström L. Hugander A. Jönsson PE. Westling H. Ehrsson $H$. Blood leakage and melphalan leakage from the perfusion circuit during regional hyperthermic perfusion for malignant melanoma. Cancer Treas Rep 1984; 68: 867-72.

11. Scoll RN. Kerr DJ. Blackie R. 't al. The pharmacokinetic advantages of isolated limb perfusion with melphalan for malignant melanoma. Br J Cancer 1992: 66: 159-66.

12. Furner RL. Brown RK. L-Phenylalanine mustard (L-PAM): the first 25 years. Cancer Treat Rep 1980: 64: 559-74.

13. Lee Y-TM. Loco-regional recurrent melanoma: II. Nonsystemic treatments (1964-1979). Cancer Trout Re' 1988; 15: 105-33.

14. Krementz ET. Regional perfusion. Current sophistication. what nexi? Cancer 1986: 57: 416-32.

15. Schraffordt Koops H. Oldhoff J. Oosterhuis JW. Beekhuis H. The role of isolated limb perfusion for regional metastases of the extremitics. Pigment Cell 1985: 7: 146-64.

16. McBride CM. Clark RL. Experience with L-phenylalanine mustard dihydrochloride in isolation-perfusion of extremities for malignant melanoma. Cancer 1971: 28: 1293-6.

17. Stehlin JS. Jr. Clark RL. Melanoma of the extremities: experiences with conventional treatment and perlusion in 339 cases. Am J Surg 1965; 110: 366-83.

18. Stehlin JS Jr, Giovanella BC. De Ipolyi PD. Mucnz LR. Anderson RF. Results of hyperthermic perfusion for melanoma of the extremities. Surg Ginecol Obstel 1975: 140: 339-48.

19. Irvine WT, Luck RJ. Review of regional limb perfusion with melphalan for malignant melanoma. Br Med J 1966: 1: 770-4.

20. Shingleton WW. Perfusion chemotherapy for recurrent melanoma of extremily: a progress report. Ann Surg 1969: 169: $969-73$.

21. Fontaine CJ, Jamieson CW. Perfusion in limb melanoma: indications and results. Proc Rol Soc Med 1974; 67: 99-100.

22. Golomb FM. Perfusion of melanoma: 133 isolated perfusions in 114 patients. Pamminerva Med 1976; 18: 8-10.

23. Hansson JA. Simert G, Vang J. The effect of regional perfusion treatment on recurrent melanoma of the extremities. Acta Chir Scand 1977: 143: 33-9.

24. Jönsson PE, Hafiström L. Hugander A. Results of regional hyperthermic perfusion for primary and recurrent melanomas of the extremities. Rec Res Cancer Res 1983: 86: 277-82.

25. Lejeune FI, Deloof T. Ewalenko P. al al. Objective regression of unexcised melanoma in-transit metastases after hyperthermic isolation perfusion of the limbs with melphalan. Rec Res Cancer Re's 1983; 86: 268-76.

26. Lejeune FJ, Liènard D. El Douaihy M. Results of 206 isolated limb perfusions for malignant melanoma. Eur $J$ Sirg Oncol 1989: 15: $510-9$.

27. Rege VB, Leone LA, Soderberg $\mathrm{CH}$, at al. Hyperthermic adjuvant perfusion chemotherapy for stage I malignant melanoma of the extremity with literature review. Cancer 1983; 52: 2033-9.

28. Minor DR. Allen RE. Alberts D, Peng Y-M, Tardelli G. Hutchinson J. A clinical and pharmacokinetic study of isolated limb perfusion with heat and melphalan for melanoma. Cancer 1985; 55: 2638-44.

29. Fletcher JR, White CR, Fletcher WS. Improved survival rates of patients with acral lentiginous melanoma treated with hyperthermic isolation perfusion, wide excision, and regional lymphadenectomy. Am J Surg 1986; 151: 593-8.

30. Vaglini M, Santinami M, Nava M, et al. Hyperthermic antiblastic perfusion in extracorporeal circulation: surgical technique and results in the treatment of extremities tumour. J Extracorpor Techol 1986: 18: 12-20.

31. Krige JEJ, King HS. Strover RM. Prophylactic hyperthermic limb perfusion in stage I melanoma. Eur J Sirrg Oncol 1988: 14: $321-6$

32. Di Filippo F, Calabro A, Giannarelli D, et al. Prognostic variables in recurrent limb melanoma treated with hyperthermic antiblastic perfusion. Cancer 1989: 63: 2551-61.

33. Santinami M. Belli F, Cascinelli N. Rovini D, Vaglini M. Seven 
years experience with hyperthermic perfusions in extracorporal circulation for melanomal of the extremities. J Surg Oncol 1989; 42: $201-8$.

34. Keltelhack Ch. Kraus Th. Hupp Th. Manner M. Schlag P. Hyperthermic limb perfusion for malignant melanoma and soft lissue sarcona. Eur J Surg Oncol 1990; 16: 370-5

35. Pace $M$. Optimization of the vascular isolation in isolated regional perfusion of the limbs. Reg Cancer Treat 1990; 3: 90-7.

36. Skenc Al. Bulman AS, Williams TR. Meirion Thomas J, Westbury G. Hyperthermic isolated perfusion with melphalan in the treatment of advanced malignant melanoma of the lower limb. Br J Surg 1990; 77: 765-7.

37. Hafström L. Rudenstam C-M, Blomquist E, et al. Regional hyperthermic perfusion with melphalan after surgery for recurrent malignant melanoma of the extremities. $J$ Clin Oncol 1990; 9: 20914 .

38. Neades GT. Evans WD, Mansel RE. Choice of agent and prediction of systemic toxicity in isolated hyperthermic limb perfusion. Reg Cancer Treal 1991: 3: 252-5.

39. Omlor G. Bahmer F. Meessen S. Zang D. Feifel G. Zaun H. Technik und Ergebnisse der hyperthermen Extremititenperfusion bei Melanompatienten (Technique and results of isolated hyperthermic limb perfusion in malignant melanoma). Langenhecks 4rch Chir 1993: 378: 2I-5.

40. Raluschecker HF. Foth H, Michaelis HC, et al. Kinetics of melphalan leakage during hyperthermic isolation perfusion in melanoma of the limb. Cancer Chemother Pharmacol 1991; 27: $379-84$.

41. Liénard D. Ewalenko P. Delmotte JJ, Renard N, Lejeune FJ. High-dose recombinant tumor necrosis factor alpha in combination with interleron gamma and melphalan in isolation perfusion of the limbs for melanoma and sarcoma. J Clin Oncol 1992: 10: 52 60 .

42. Lejeune FJ. Liénard D. Leyvraz S. Mirimanoft RO. Regional therapy of melanoma. Eur J Cancer 1003: 29A: 606-12.

43. Vaglini M. Belli F. Ammatuna M. ot al. Treatment of primary or relapsing limb cancer by isolation perfusion with high-dose alpha-lumor necrosis factor, gamma-interferon, and melphalan. Cancer 1994: 73: 483-9?

44. Sigurdsson GH. Nachbur B. Lejeune FJ. Anesthesiologists' management of isolated limb perfusion with 'high-dose' tumor necrosis factor a. Anesthesiology' 1993: 79: 1433-7

45. Kroon BBR. Regional isolation perfusion in melanoma of the limbs; accomplishments, unsolved problems, future. Eur I Surg Oncol 1988; 14: 101-10.

46. EORTC malignant melanoma cooperative group. Protocol 18832: a randomized trial on prophylactic isolation perfusion for stage I high risk ( $\geq 1.5 \mathrm{~mm}$ thickness) malignant melanoma of the limbs. Brussels, Belgium, 1984: 1-21.

47. Kroon BBR. Klaase JM, Van Geel AN, Eggermont AMM. Application of hyperthermia in regional isolated perfusion for melanoma of the limbs. Reg Cancer Treat 1992: 4: 223-6.

48. Wieberdink J. Benckhuijsen C. Braal RP. Van Slooten EA. Olthius GAA. Dosimetry in isolation perfusion of the limbs by assessment of perfused tissue volume and grading of toxic tissue reactions. Eur J Cancer Clin Oncol 1982; 18, 905-10.

49. Benckhuijsen C. Kroon BBR. Van Geel AN, Wieberdink J. Regional perlusion treatment with melphalan for melanoma in a limb: an evaluation of drug kinetics. Eur J Surg Oncol 1988: 14: 157-63.

50. Stehlin JS, Clark RL. Dewey WC. Continuous monitoring of leakage during regional perfusion. Arch Surg 1961; 83: 165-71.

51. World Health Organization (WHO). WHO handbook for reporting results of cancer treatment. Geneva: WHO ofiset publication No. 48, 1979.

52. Klatase JM, Kroon BBR, Van Geel AN. Eggermont AMM. Franklin HR. Systemic leakage during isolated limb perfusion for melanoma. Br J Sirg 1993; 80: 1124-6.

53. Hoekstra HJ, Naujocks T. Schraffordt Koops, H, et al. Continuous leakage monitoring during hyperthermic isolated regional perfusion of the lower limb: techniques and results. Reg Cancer Treal 1992: 4: 301-4.
54. Benckhuijsen C. Varossieau FJ, Hart AAM, Wieberdink J. Noordhoek J. Pharmacokinetics of melphalan in isolated perfusion of the limbs. J Pharmacol Exp Ther 1986: 237: 583-8.

55. Thompson JF, Malouf DJ, Merzliakov S. Kam PCA. Efficacy of single-dose ondansetron in the prevention of post-operative nausea and vomiting following isolated limb perfusion with cytostatic agents. Reg Cancer Treat 1993; 4: 177-82.

56. Sear JW. Roscwarme F. Anaesthesia for surgeons. In: Morris PJ. Malt RA (eds) Oxford Texthook of Surgery. New York: Oxford University Pres, 1994: 53-82.

57. Beck TM. Eflicacy of ondansetron tablets in the management of chemotherapy-induced emesis: review of clinical trials. Semin Oncol 1992: 19 (Suppl. 15): 20-5.

58. Brown GW. Paes D, Bryson J. Freeman AJ. The effectiveness of a single intravenous dose of ondansetron. Oncology 1992: 49: 273-8

59. Perez EA. Gandara DR. Advances in the control of chemotherapy-induced emesis. Am Oncol 1992; 3 (Suppl. 3): $47-50$.

60. Watcha MF, White PF. Postoperative nausea and vomiting: its etiology, treatment and prevention. Anesthesiology 1992; 77: 162-84.

61. Russell D, Kenny GNC. 5-HT 3 antagonists in postoperative nausea and vomiting. Br J Ancesth 1992; 69 (Suppl. 1): 63S-68S.

62. Slapak CA. Kufe DW. Principles of cancer therapy. In: Isselbacher KJ, Brauwald E. Wilson JD. Martin JB, Fauci AS. Kasper DL. (eds) Harrison's Principles of Internal Medicine (13th edn). New York: McGraw-Hill, 1994: 1826-40.

63. Boddie AW, Briele H, Krementz ET. A phase I study of melphalan in 40 degrees $C$ isolated limb perfusion using packed red blood cells and lactated Ringer's perlusate (abstract). Proc ASCO 1992: 11: 351

64. Didolkar MS, Fitzpatrick JL, Jackson AJ, Johnston GS. Toxicity and complications of vascular isolation and hyperthermic perfusion with imidazole carboxamide (DTIC) in melanoma. Cancer 1986: 57: 1961-6.

65. Ghussen F. Nagel K. Groth W. Müller JM. Stützer H. A prospective randomized study of regional extremity perfusion in patients with malignant melanoma. Anm Surg 1984; 200: +768 .

66. Matsen FA. Compartmental syndrome: an unified concept. Clin Orthop Rel Res 1975; 113: 8-14.

67. Reneman RS. The anterior and lateral compartmental syndrome of the leg due to intensive use of muscles. Clin Orthop Rel Res 1975: 113: 69-79.

68. Fraker DL. Alexander HR. Isolated limb perfusion with highdose tumor necrosis factor for extremity melanoma and sarcoma. In: DeVita VT. Hellman S. Rosenberg SA (eds) Important Advances in Oncology 1994. Philadelphia: JB Lippincoll Company, 1994: 179-92.

69. Liénard D. Eggermont AMM. Schraftordt Koops H. et al. Isolated perfusion with high-dose tumor necrosis factor-alpha. interferon-gamma and melphalan for melinnoma stage III: results of a multicenter pilot study. Melanoma Res 1994; 4 (Suppl. 1): 21-6.

70. Gérain J, Liènard D. Ewalenko P. Lejeune FJ. High serum levels of TNF $\alpha$ after its administration for isolation perfusion of the limbs. Cytokine 1992; 4: 585-91.

71. Thom AK, Alexander HR, Andrich MP, Barker WC. Rosenberg SA. Fraker DL. Cytokine levels and systemic toxicity in patients undergoing isolated limb perfusion with high-dose tumor necrosis factor. interferon gamma. and melphalan. J Clin Oncol 1995; 13: 264-73.

72. Swaak AJG, Liénard D, Schraffordt Koops H, Lejeune FJ, Eggermont AMM. Effects of recombinant tumor necrosis factor alpha $(\mathrm{rTNF} \alpha)$ in cancer: observations of the acute phase protein reaction and immunoglobin synthesis after high dose rTNF $x$ administration in isolated limb perfusions in cancer patients. Eur J Clin Im 1993; 23: 812-8.

Accepted for publication 5 June 1996 